\title{
Shell occupation by the endemic western Atlantic hermit crab Isocheles sawayai (Diogenidae) from Caraguatatuba, Brazil
}

\author{
Fantucci, MZ., Biagi, R. and Mantelatto, FL.* \\ Laboratório de Bioecologia e Sistemática de Crustáceo, Departamento de Biologia, \\ Faculdade de Filosofia, Ciências e Letras de Ribeirão Preto - FFCLRP, \\ Universidade de São Paulo - USP, \\ Av. Bandeirantes 3900, CEP 14040-901, Ribeirão Preto, SP, Brazil \\ *e-mail: flmantel@usp.br
}

Received February 28, 2007 - Accepted May 10, 2007 - Distributed November 30, 2008

(With 2 figures)

\begin{abstract}
The aim of this study was to characterize the pattern of shell occupation by the hermit crab Isocheles sawayai Forest and Saint-Laurent, 1968, from the Caraguatatuba region. The percentage of shell types that were occupied and the morphometric relationships between hermit crabs and occupied shells were analyzed from systematized collections that were conducted monthly from July 2001 to June 2003 . A total of 373 individuals were captured (297 males, 41 non-ovigerous females, 25 ovigerous females and 10 intersexes), occupying 17 species of gastropod shells. Stramonita haemastoma (Linnaeus, 1767) (49.87\%) was the significantly most occupied species $\left(\chi^{2}=89.30\right.$; $\mathrm{P}<0.05)$ followed, with no significant difference, by Phalium granulatum (Born, 1778) (11.53\%), Polinices hepaticus (Roding, 1798) (8.31\%) and Cymatium parthenopeum (von Salis, 1793) (6.97\%). All the morphometric relationships between hermit crabs and occupied shells showed high $(\mathrm{r}>0.68)$ and significant $(\mathrm{P}<0.05)$ correlation values, which is an important indication that in this I. sawayai population the animals occupied adequate shells. The high number of occupied shell species and relative plasticity indicated that, for the studied population, occupation is influenced by the shell availability.
\end{abstract}

Keywords: Anomura, Crustacea, shell utilization, gastropod shells.

\section{Ocupação de conchas pelo ermitão endêmico do Atlântico ocidental Isocheles sawayai (Diogenidae) em Caraguatatuba, Brasil}

\begin{abstract}
Resumo
O presente estudo caracterizou o padrão de ocupação de conchas de Isocheles sawayai Forest and Saint-Laurent, 1968, na região de Caraguatatuba. A porcentagem dos diferentes tipos de conchas ocupadas e as relações morfométricas entre os ermitões e as conchas ocupadas foram analisadas a partir de material de amostragem sistematizada, mensalmente, de julho/2001 a junho/2003. Foram capturados 373 indivíduos (297 machos, 41 fêmeas não-ovígeras, 25 fêmeas ovígeras e 10 indivíduos intersexo), ocupando 17 espécies de conchas de moluscos gastrópodes. Stramonita haemastoma (Linnaeus, 1767) $(49,87 \%)$ foi a espécie significativamente mais ocupada $\left(\chi^{2}=89,30 ; \mathrm{p}<0,05\right)$ seguida, porém sem diferença significativa, por Phalium granulatum (Born, 1778) (11,53\%), Polinices hepaticus (Roding, 1798) (8,31\%) e Cymatium parthenopeum (von Salis, 1793) (6,97\%). Todas as relações morfométricas entre os ermitões e as conchas ocupadas apresentaram valores de coeficientes de correlação elevados $(r>0,68)$ e significativos ( $\mathrm{p}<0,05)$, o que é um importante indício de que, nessa população de $I$. sawayai, os animais ocupavam conchas adequadas. O elevado número de espécies de conchas ocupadas e a relativa plasticidade indicaram que, para a população estudada, a ocupação é influenciada pela disponibilidade de conchas.
\end{abstract}

Palavras-chave: Anomura, Crustacea, utilização de conchas, conchas de gastrópodes.

\section{Introduction}

The intriguing mechanism of shell occupation developed by hermit crabs is intimately related to the protection of the non-calcified abdomen against predators (Reese, 1969; Vance, 1972a) and other hermit crabs (Conover, 1978), and against mechanic abrasions, desic-

cation, osmotic and thermal stress (Reese, 1969; Bollay, 1964; Bertness, 1981a; 1982). However, the shell may limit the hermit crab growth (Markham, 1968; Vance, 1972a), influence the fecundity and the spawn size and restrict reproduction and population growth (Provenzano, 
1960; Bollay, 1964; Vance, 1972a; Fotheringham, 1976a; 1976b; Scully, 1983; Lancaster, 1988; Mantelatto et al., 2002). Furthermore, according to Hazlett and Baron (1989) the shell may also interfere in sexual selection and copulatory behavior of hermit crabs. In this way, the strong association between these animals and their shelter has greatly influenced almost all aspects of their biology (Hazlett, 1981). This association does not occur casually (Hazlett, 1981), because shell selection by hermit crabs is influenced by diverse shell variables such as weight, size, shape, internal volume, occurrence of exobionts and resistance to predation and desiccation (Hazlett, 1981; Abrams, 1988; Martinelli and Mantelatto, 1998; Mantelatto and Dominciano, 2002).

Shell occupation by hermit crabs has been the subject of many studies throughout the past decades. In Brazil, research developed with shallow water species from the littoral coast of São Paulo state constitute pioneer studies about this aspect in the western South Atlantic: Bertini and Fransozo (2000), Garcia and Mantelatto (2000), Mantelatto and Garcia (2000), Mantelatto and Dominciano (2002), Meireles et al. (2003), Dominciano and Mantelatto (2004), Mantelatto and Meireles (2004), Meireles and Mantelatto (2005) and Terossi et al. (2006).

Isocheles sawayai Forest and Saint-Laurent, 1968 is a filter infralittoral benthic species that lives partially buried in sand bottom, in moderate and low profundities (Melo, 1999). The geographical distribution of this species is restricted to the western Atlantic coast, from Venezuela to Brazil (Santa Catarina) (Coelho and Ramos, 1972; Nucci and Melo, 2000).

The pattern of shell occupation of I. sawayai previously described by other authors in Brazil was made through a concentrated effort of capture during a specific period, which may not reflect all the necessary information about this aspect. In this context, this paper characterized the pattern of gastropod shell occupation by I. sawayai, in the Caraguatatuba region, northern littoral of São Paulo state coast, by systematized collection and analysis, using the percentage of shell occupation and demonstrating the shell variables that best fit the hermit crabs. Such information contributes to a better understanding of the poor knowledge of the biology of this species as well as of other shallow water ones on the western coast.

\section{Material and Methods}

The hermit crabs were collected monthly from July 2001 to June 2003, in the Caraguatatuba region $\left(23^{\circ} 36^{\prime} 08^{\prime \prime}-23^{\circ} 47^{\prime} 07^{\prime \prime} \mathrm{S}\right.$ and $45^{\circ} 20^{\prime} 03^{\prime \prime}-45^{\circ} 08^{\prime} 30^{\prime \prime}$ $\mathrm{W})$, on the northern littoral coast of São Paulo state, using a fishing boat with two double-rig trawl nets $(20 \mathrm{~mm}$ mesh size in the net body and $15 \mathrm{~mm}$ in the cod end). Each sample was of approximately 30 minutes, at two knots main velocity.
After collection the specimens were sorted, frozen and transported to the laboratory where they were removed form their shells, counted, weighed (wet weight, WW), measured for the shield length (SL) and width (SW), and the left chelar propodus length (LPL). The sex was identified by the gonopore position.

The species of occupied gastropod shells were identified according to Rios (1994), and measured for the aperture length (SAL) and width (SAW), and dry weight (SDW). The shell internal volume (SIV) was obtained according to Bertness (1981b), modified by Mantelatto and Garcia (2000), determining the sand volume (diameter of 0.25 to $0.125 \mathrm{~mm}$ ) required to fill the empty shell. Occurrence of epibionts on the external surface of occupied shells was checked with no characterization of the position of infestation. Epibionts were identified at the major group level and the percentage of each group was calculated.

The percentage of the different occupied shell species was tested by the chi-square, and the size of occupied shells was evaluated by ANOVA on Ranks. Relationships between occupied shells and hermit crab dimensions were verified by regression analysis and correlation coefficients. The level of significance adopted was 0.05 (Zar, 1996). The specimens collected are deposited in the Crustacean Collection of the Biology Department of the Faculty of Philosophy, Sciences and Letters of Ribeirão Preto, University of São Paulo, Brazil (CCDB/FFCLRP/USP, accession numbers 1687-1691).

\section{Results}

Throughout the two year sampling period, a total of 373 I. sawayai specimens was collected: 297 males (79.62\%), 41 non-ovigerous females (10.99\%), 25 ovigerous females $(6.70 \%)$ and 10 intersex individuals $(2.68 \%)$ (Table 1$)$. The size frequency distribution of the population presented a normal pattern with a unimodal distribution $(\mathrm{KS}=0.034, \mathrm{P}>0.20)$ and the same was observed for each group of interest (males: KS $=0.036$, $\mathrm{P}>0.20$; ovigerous females: $\mathrm{KS}=0.109, \mathrm{P}>0.20$; and intersexes: $K S=0.188 ; \mathrm{P}>0.20$ ), with the exception of non-ovigerous females that exhibited a unimodal pattern with non-normal distribution $(\mathrm{KS}=0.146 ; \mathrm{P}=0.024)$ (Figure 1).

The hermit crabs were found inhabiting 17 species of gastropod shells in different percentages. Stramonita haemastoma was the significantly most occupied species $\left(49.87 \%, \chi^{2}=89.30, \mathrm{P}<0.05\right)$ by the $I$. sawayai population, followed with no significant difference, by Phalium granulatum (11.53\%), Polinices hepaticus (8.31\%), Cymatium parthenopeum (6.97\%), Olivancilaria urceus (5.63\%), Buccinanops gradatum (5.09\%), Chicoreus tenuivaricosus (3.75\%) and Strombus pugilis (3.49\%) (Table 1). The remaining shell species showed a variable occupation percentage ( 0.27 to $1.88 \%)$ represent- 
Table 1. Isocheles sawayai. Percentage of gastropod shell species occupation in the Caraguatatuba region (SP).

\begin{tabular}{|c|c|c|c|c|c|c|c|c|c|c|}
\hline \multirow[t]{2}{*}{ Species } & \multicolumn{2}{|c|}{ Total } & \multicolumn{2}{|c|}{ MA } & \multicolumn{2}{|c|}{ NOF } & \multicolumn{2}{|c|}{ OF } & \multicolumn{2}{|c|}{ I } \\
\hline & $\mathrm{n}$ & $\%$ & $\mathrm{n}$ & $\%$ & $\mathbf{n}$ & $\%$ & $\mathbf{n}$ & $\%$ & $\mathrm{n}$ & $\%$ \\
\hline $\begin{array}{l}\text { Buccinanops gradatum } \\
\text { (Deshayes, 1844) }\end{array}$ & 19 & 5.09 & 13 & 4.38 & 4 & 9.76 & 2 & 8.00 & 0 & 0.00 \\
\hline $\begin{array}{l}\text { Chicoreus tenuivaricosus } \\
\text { (Dautzenberg, 1927) }\end{array}$ & 14 & 3.75 & 10 & 3.37 & 3 & 7.32 & 0 & 0.00 & 10 & 3.37 \\
\hline $\begin{array}{l}\text { Cymatium parthenopeum } \\
\text { (von Salis, 1793) }\end{array}$ & 26 & 6.97 & 25 & 8.42 & 0 & 0.00 & 1 & 4.00 & 25 & 8.42 \\
\hline $\begin{array}{l}\text { Dorsanum moniliferum } \\
\text { (Valenciennes, 1834) }\end{array}$ & 4 & 1.07 & 3 & 1.01 & 1 & 2.44 & 0 & 0.00 & 3 & 1.01 \\
\hline $\begin{array}{l}\text { Fusinus brasiliensis } \\
\text { (Grabau, 1904) }\end{array}$ & 3 & 0.80 & 3 & 1.01 & 0 & 0.00 & 0 & 0.00 & 3 & 1.01 \\
\hline $\begin{array}{l}\text { Leucozonia nassa } \\
\text { (Gmelin, 1791) }\end{array}$ & 1 & 0.27 & 0 & 0.00 & 0 & 0.00 & 0 & 0.00 & 0 & 0.00 \\
\hline $\begin{array}{l}\text { Natica isabelleana } \\
\text { Orbigny, } 1840\end{array}$ & 1 & 0.27 & 0 & 0.00 & 1 & 2.44 & 0 & 0.00 & 0 & 0.00 \\
\hline $\begin{array}{l}\text { Olivancillaria urceus } \\
\text { (Roding, 1798) }\end{array}$ & 21 & 5.63 & 19 & 6.40 & 2 & 4.88 & 0 & 0.00 & 19 & 6.40 \\
\hline $\begin{array}{l}\text { Olivancillaria vesica } \\
\text { (Gmelin, 1791) }\end{array}$ & 7 & 1.88 & 4 & 1.35 & 3 & 7.32 & 0 & 0.00 & 4 & 1.35 \\
\hline $\begin{array}{l}\text { Phalium granulatum } \\
\text { (Born, 1778) }\end{array}$ & 43 & 11.53 & 42 & 14.14 & 0 & 0.00 & 0 & 0.00 & 1 & 10.00 \\
\hline $\begin{array}{l}\text { Pisania auritula } \\
\text { (Link, 1807) }\end{array}$ & 1 & 0.27 & 0 & 0.00 & 1 & 2.44 & 0 & 0.00 & 0 & 0.00 \\
\hline $\begin{array}{l}\text { Pisania pusio } \\
\text { (Linnaeus, 1758) }\end{array}$ & 1 & 0.27 & 1 & 0.34 & 0 & 0.00 & 0 & 0.00 & 0 & 0.00 \\
\hline $\begin{array}{l}\text { Polinices hepaticus } \\
\text { (Roding, 1798) }\end{array}$ & 31 & 8.31 & 23 & 7.74 & 6 & 14.63 & 2 & 8.00 & 0 & 0.00 \\
\hline $\begin{array}{l}\text { Polinices lacteus } \\
\text { (Guilding, 1833) }\end{array}$ & 1 & 0.27 & 1 & 0.34 & 0 & 0.00 & 0 & 0.00 & 0 & 0.00 \\
\hline $\begin{array}{l}\text { Stramonita haemastoma } \\
\text { (Linnaeus, 1767) }\end{array}$ & 186 & 49.87 & 143 & 48.15 & 19 & 46.34 & 17 & 68.00 & 7 & 70.00 \\
\hline $\begin{array}{l}\text { Strombus pugilis } \\
\text { Linnaeus, } 1758\end{array}$ & 13 & 3.49 & 9 & 3.03 & 1 & 2.44 & 3 & 12.00 & 0 & 0.00 \\
\hline $\begin{array}{l}\text { Tegula viridula } \\
\text { (Gmelin, 1791) }\end{array}$ & 1 & 0.27 & 1 & 0.34 & 0 & 0.00 & 0 & 0.00 & 0 & 0.00 \\
\hline Total & 373 & 100.00 & 297 & 100.00 & 41 & 100.00 & 25 & 100.00 & 10 & 100.00 \\
\hline
\end{tabular}

n: number of individuals; MA: males; NOF: non-ovigerous females; OF: ovigerous females; and I: intersexes.

ing $5.36 \%$ of the total occupied shell species, and were grouped and named as others.

Stramonita haemastoma was also significantly the most occupied species for each group of interest (males: $48.15 \%, \chi^{2}=55.14$; non-ovigerous females: $46.36 \%$, $\chi^{2}=6.76$; ovigerous females: $68.00 \%, \chi^{2}=9.80$ and intersexes: $70.00 \%, \chi^{2}=4.50 ; \mathrm{P}<0.05$ ), while for the remaining occupied shell species a variable pattern was exhibited (Table 1).

Males and non-ovigerous females were observed inhabiting 14 and 10 of the 17 shell species occupied by I. sawayai, respectively, which represents a more diversified occupation pattern than that exhibited by the other groups of individuals (ovigerous females $=5$; intersexes $=4)($ Table 1$)$. A greater shell species diversity occupation was observed for intermediate sized individuals (4.4-8.6 mm of SL) (Figure 2).

The shells occupied by males, ovigerous females and intersexes were not significantly different for aperture length and dry weight but were significantly larger than those occupied by non-ovigerous females. Shells occupied by males and intersexes had similar aperture width which were significantly larger than those occupied by females (non ovigerous and ovigerous). Shell internal volume was not significantly different among the groups of individuals.

Epibionts occurred on the external surface of $57.37 \%$ $(\mathrm{n}=214)$ of $I$. sawayai occupied shells, and on 14 of 


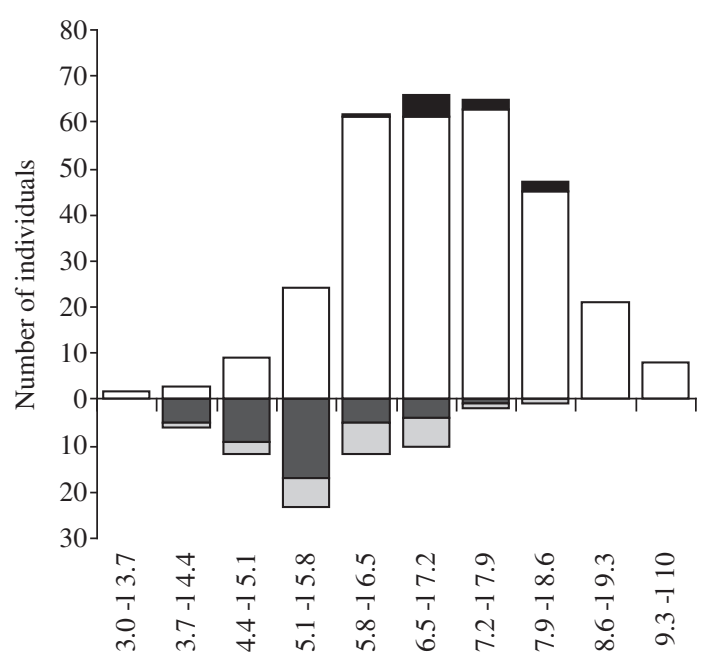

Shield length (mm)

$\begin{array}{ll}\square \text { Non ovigerous females } & \square \text { Intersex } \\ \square \text { Ovigerous females } & \square \text { Males }\end{array}$

Figure 1. Isocheles sawayai. Size frequency distribution for each group of interest of individuals collected in Caraguatatuba region (SP).

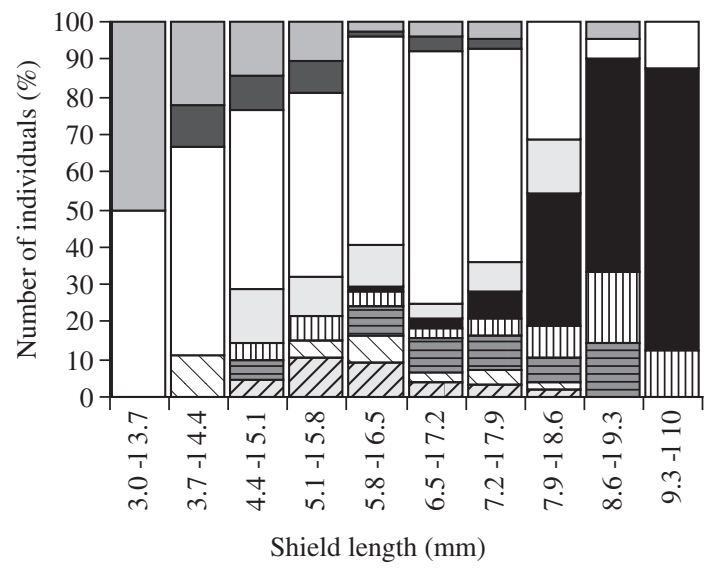

\begin{tabular}{|c|c|c|}
\hline$\bigotimes B$. gradatum & C. tenuivaricosu. & 目C.parthenopeum \\
\hline$\square O$. urceus & P. granulatum & $\square$ P. hepaticus \\
\hline$\square$ S. haemastoma & S. pugilis & $\square$ Others \\
\hline
\end{tabular}

Figure 2. Isocheles sawayai. Occupancy percentage of the different gastropod shell species for the size classes, in Caraguatatuba region (SP).

the 17 occupied species. Of the total analyzed shells, $42.36 \%$ had bryozoans $(n=158), 19.84 \%$ polychaete tubes $(\mathrm{n}=74), 14.75 \%$ bivalve molluscs $(\mathrm{n}=55), 1.88 \%$ barnacles $(n=7), 0.80 \%$ cnidarians $(n=3)$ and $0.27 \%$ ophiuroides $(\mathrm{n}=1)$.

All regression analysis between hermit crabs and shell measures for the total occupied shells exhibited high $(r>0.68)$ and significant correlation coefficients (Table 2). Among them, the relationships with the shell internal volume (SIV) showed the highest values of correlation coefficients. In relation to the animals' dimensions, the relationships of the wet weight (WW) exhibited the highest values of correlation coefficients. Thus, SIV $x$ WW was the relationship that best described the association between the hermit crabs and the occupied shells. Regression analyzes of the four most occupied shell species by I. sawayai (S. haemastoma, $P$. granulatum, $P$. hepaticus and $C$. parthenopeum) were evaluated and, all analyzed relations showed significant correlations $(\mathrm{P}<0.05)$ (Table 2$)$. The lowest correlation coefficients were verified by animals inhabiting P. granulatum (Table 2).

\section{Discussion}

Isocheles sawayai occupied 17 gastropod shell species in the Caraguatatuba region, a great number when compared with a previous study that recorded I. sawayai occupying only six gastropod shell species (Pinheiro et al., 1993) probably as a result of a non systematized effort of collection. Stramonita haemastoma was the one most occupied by the studied population (49.87\%). This occupation percentage can be considered moderate when compared to other I. sawayai populations and other hermit crab species, which inhabited the most occupied shell species in higher percentages (60.6 to 90\%) (Hebling and Wernick, 1974; Pinheiro et al., 1993; Bertini and Fransozo, 2000; Floeter et al., 2000; Biagi et al., 2006; Terossi et al., 2006). Considering that some shell species were occupied accidentally and almost half of the population inhabited one shell species in particular, I. sawayai showed a high plasticity in relation to shell diversity occupation which was also exhibited by this hermit crab population in Venezuela (Galindo et al., 2008). A similar pattern of plasticity on shell occupation was related for other shallow water hermit crab species (Mantelatto and Garcia, 2000; Mantelatto and Dominciano, 2002; Mantelatto and Meireles, 2004; Meireles, 2006, respectively) on the northern littoral coast of São Paulo state.

According to Bertness (1980), shell utilization patterns are determined by the hermit crab preference for a shell species, gastropod shell availability in the environment and interspecific competition. Considering that empty gastropod shells are often scarce in habitats of hermit crab populations (Childress, 1972; Bach et al., 1976; Kellog, 1976; Abrams, 1980; Bertness, 1980), and that in natural populations hermit crabs are frequently observed in shells smaller than those selected in laboratory experiments (Vance, 1972a; 1972b; Bach et al., 1976; Bertness, 1980), it can be concluded that empty shell availability in the environment is a factor of great influence on shell occupation (Mantelatto and Garcia, 2000; Meireles et al., 2003; Mantelatto and Meireles, 2004). 
Table 2. Isocheles sawayai. Regression equations for the relations between hermit crabs and the four most occupied shell species dimensions, in Caraguatatuba region (SP).

\begin{tabular}{|c|c|c|c|c|c|}
\hline Shell species & Relations & $\mathbf{n}$ & $\begin{array}{c}\text { Linear equation } \\
\mathbf{Y}=\mathbf{a X b} \\
\end{array}$ & $\begin{array}{c}\text { Transformed } \\
\ln y=\ln a+b \ln x\end{array}$ & $\mathbf{r}$ \\
\hline \multirow[t]{12}{*}{ Total } & SL $\times$ SAL & 373 & $\mathrm{SAL}=3.59 \mathrm{SL}^{1.06}$ & $\operatorname{lnSAL}=1.28+1.06 \operatorname{lnSL}$ & $0.73 *$ \\
\hline & SL $\times$ SAW & 373 & $\mathrm{SAW}=1,84 \mathrm{SL}^{0.95}$ & $\operatorname{lnSAW}=0.61+0.95 \operatorname{lnSL}$ & $0.78 *$ \\
\hline & SL $\times$ SDW & 373 & $\mathrm{SDW}=0.05 \mathrm{SL}^{2.68}$ & $\operatorname{lnSDW}=-2.98+2.68 \operatorname{lnSL}$ & $0.76^{*}$ \\
\hline & SL $\times$ SIV & 271 & $\mathrm{SIV}=0.01 \mathrm{SL}^{3.15}$ & $\operatorname{lnSIV}=-4.64+3.15 \operatorname{lnSL}$ & $0.85^{*}$ \\
\hline & LPL x SAL & 372 & $\mathrm{SAL}=3.72 \mathrm{LPL}^{0.94}$ & $\operatorname{lnSAL}=1.31+0.94 \operatorname{lnLPL}$ & $0.73 *$ \\
\hline & LPL x SAW & 372 & $\mathrm{SAW}=2.01 \mathrm{LPL}^{0.81}$ & $\operatorname{lnSAW}=0.70+0.81 \operatorname{lnLPL}$ & $0.75^{*}$ \\
\hline & LPL $\times$ SDW & 372 & $\mathrm{SDW}=0.07 \mathrm{LPL}^{2.26}$ & $\operatorname{lnSDW}=-2,66+2.26 \operatorname{lnLPL}$ & $0.72 *$ \\
\hline & LPL $\times$ SIV & 270 & $\mathrm{SIV}=0.01 \mathrm{LPL}^{2.78}$ & $\operatorname{lnSIV}=-4.53+2.78 \operatorname{lnLPL}$ & $0.84 *$ \\
\hline & WW x SAL & 373 & $\mathrm{SAL}=19.77 \mathrm{WW}^{0.32}$ & $\operatorname{lnSAL}=2.98+0.32 \ln \mathrm{WW}$ & $0.76^{*}$ \\
\hline & WW x SAW & 373 & $\mathrm{SAW}=8.47 \mathrm{WW}^{0.28}$ & $\operatorname{lnSAW}=2.14+0.28 \ln W W$ & $0.79 *$ \\
\hline & WW $\times$ SDW & 373 & $\mathrm{SDW}=3.79 \mathrm{WW}^{0.79}$ & $\operatorname{lnSDW}=1.33+0.79 \ln W W$ & $0.77 *$ \\
\hline & WW $\times$ SIV & 271 & $\mathrm{SIV}=1.47 \mathrm{WW}^{0.96}$ & $\operatorname{lnSIV}=0.39+0.96 \ln W W$ & $0.89 *$ \\
\hline \multirow[t]{12}{*}{ S. haemastoma } & SL x SAL & 186 & $\mathrm{SAL}=4.86 \mathrm{SL}^{0.88}$ & $\operatorname{lnSAL}=1.58+0.88 \ln S \mathrm{~L}$ & $0.77 *$ \\
\hline & SL $\times$ SAW & 186 & $\mathrm{SAW}=1.65 \mathrm{SL}^{1.03}$ & $\operatorname{lnSAW}=0.50+1.03 \operatorname{lnSL}$ & $0.79 *$ \\
\hline & SL $\times$ SDW & 186 & $\mathrm{SDW}=0.04 \mathrm{SL}^{2.71}$ & $\operatorname{lnSDW}=-3.13+2.71 \operatorname{lnSL}$ & $0.79 *$ \\
\hline & SL $\times$ SIV & 131 & $\mathrm{SIV}=0.02 \mathrm{SIV}^{2.81}$ & $\operatorname{lnSIV}=-4.14+2.81 \operatorname{lnSL}$ & $0.83 *$ \\
\hline & LPL x SAL & 185 & $\mathrm{SAL}=5.88 \mathrm{LPL}^{0.70}$ & $\operatorname{lnSAL}=1.77+0.70 \operatorname{lnLPL}$ & $0.72 *$ \\
\hline & LPL x SAW & 185 & $\mathrm{SAW}=2.11 \mathrm{LPL}^{0.81}$ & $\operatorname{lnSAW}=0.75+0.81 \operatorname{lnLPL}$ & $0.73 *$ \\
\hline & LPL $x$ SDW & 185 & $\mathrm{SDW}=0.11 \mathrm{LPL}^{1.99}$ & $\operatorname{lnSDW}=-2.17+1.99 \operatorname{lnLPL}$ & $0.68 *$ \\
\hline & LPL $\times$ SIV & 130 & $\mathrm{SIV}=0.03 \mathrm{LPL}^{2.26}$ & $\operatorname{lnSIV}=-3.56+2.26 \operatorname{lnLPL}$ & $0.77 *$ \\
\hline & WW x SAL & 186 & $\mathrm{SAL}=19.94 \mathrm{WW}^{0.27}$ & $\operatorname{lnSAL}=2.99+0.27 \ln W W$ & $0.82 *$ \\
\hline & WW x SAW & 186 & $\mathrm{SAW}=8.73 \mathrm{WW}^{0.31}$ & $\operatorname{lnSAW}=2.17+0.31 \ln W W$ & $0.83^{*}$ \\
\hline & WW x SDW & 186 & $\mathrm{SDW}=3.56 \mathrm{WW}^{0.79}$ & $\operatorname{lnSDW}=1.27+0.79 \ln W W$ & $0,81 *$ \\
\hline & WW $x$ SIV & 131 & $\mathrm{SIV}=1.46 \mathrm{WW}^{0.86}$ & $\operatorname{lnSIV}=0.38+0.86 \ln W W$ & $0.88 *$ \\
\hline \multirow[t]{12}{*}{ P. granulatum } & SL x SAL & 43 & $\mathrm{SAL}=7.89 \mathrm{SL}^{0.73}$ & $\operatorname{lnSAL}=2.07+0.73 \operatorname{lnSL}$ & $0.63 *$ \\
\hline & SL $x$ SAW & 43 & $\mathrm{SAW}=3.19 \mathrm{SL}^{0.68}$ & $\operatorname{lnSAW}=1.16+0.69 \operatorname{lnSL}$ & $0.55^{*}$ \\
\hline & SL $\times$ SDW & 43 & $\mathrm{SDW}=0.11 \mathrm{SL}^{2.26}$ & $\operatorname{lnSDW}=-2.19+2.26 \operatorname{lnSL}$ & $0.49 *$ \\
\hline & SL $\times$ SIV & 34 & $\mathrm{SIV}=0.13 \mathrm{SL}^{2.11}$ & $\operatorname{lnSIV}=-2.05+2.11 \operatorname{lnSL}$ & $0.61 *$ \\
\hline & LPL x SAL & 43 & $\mathrm{SAL}=7.21 \mathrm{LPL}^{0.69}$ & $\operatorname{lnSAL}=1.98+0.69 \operatorname{lnLPL}$ & $0.56^{*}$ \\
\hline & LPL x SAW & 43 & $\mathrm{SAW}=3.12 \mathrm{LPL}^{0.63}$ & $\operatorname{lnSAW}=1.14+0.63 \operatorname{lnLPL}$ & $0.47 *$ \\
\hline & LPL $x$ SDW & 43 & $\mathrm{SDW}=0.20 \mathrm{LPL}^{1.72}$ & $\operatorname{lnSDW}=-1.61+1.79 \operatorname{lnLPL}$ & $0.37 *$ \\
\hline & LPL $x$ SIV & 34 & $\mathrm{SIV}=0.05 \mathrm{LPL}^{2.30}$ & $\operatorname{lnSIV}=-2.98+2.30 \operatorname{lnLPL}$ & $0.58^{*}$ \\
\hline & WW x SAL & 43 & $\mathrm{SAL}=24.41 \mathrm{WW}^{0.23}$ & $\operatorname{lnSAL}=3.19+0.23 \ln W W$ & $0.61 *$ \\
\hline & WW x SAW & 43 & $\mathrm{SAW}=9.32 \mathrm{WW}^{0.21}$ & $\operatorname{lnSAW}=2.23+0.21 \ln W W$ & $0.53 *$ \\
\hline & WW x SDW & 43 & $\mathrm{SDW}=3.38 \mathrm{WW}^{0.77}$ & $\operatorname{lnSDW}=1.22+0.77 \ln W W$ & $0.52 *$ \\
\hline & WW x SIV & 34 & $\mathrm{SIV}=3.47 \mathrm{WW}^{0.66}$ & $\operatorname{lnSIV}=1.25+0.66 \ln W W$ & $0.58 *$ \\
\hline \multirow[t]{12}{*}{ P. hepaticus } & SL x SAL & 31 & $\mathrm{SAL}=4.73 \mathrm{SL}^{0.80}$ & $\operatorname{lnSAL}=1.55+0.80 \ln S \mathrm{~L}$ & $0.82 *$ \\
\hline & SL $\times$ SAW & 31 & $\mathrm{SAW}=2.20 \mathrm{SAW}^{0.88}$ & $\operatorname{lnSAW}=0.79+0.88 \ln \mathrm{SL}$ & $0.79 *$ \\
\hline & SL $\times$ SDW & 31 & $\mathrm{SDW}=0.04 \mathrm{SL}^{2.84}$ & $\operatorname{lnSDW}=-3.16+2.84 \operatorname{lnSL}$ & $0.83^{*}$ \\
\hline & SL $\times$ SIV & 30 & $\mathrm{SIV}=0.02 \mathrm{SL}^{2.70}$ & $\operatorname{lnSIV}=-3.76+2.70 \ln S \mathrm{~L}$ & $0.83 *$ \\
\hline & LPL x SAL & 31 & $\mathrm{SAL}=5.02 \mathrm{LPL}^{0.69}$ & $\operatorname{lnSAL}=1.61+0.69 \operatorname{lnLPL}$ & $0.83 *$ \\
\hline & LPL x SAW & 31 & $\mathrm{SAW}=2.36 \mathrm{LPL}^{0.75}$ & $\operatorname{lnSAW}=0.86+0.75 \operatorname{lnLPL}$ & $0.80 *$ \\
\hline & LPL $x$ SDW & 31 & $\mathrm{SDW}=0.05 \mathrm{LPL}^{2.49}$ & $\operatorname{lnSDW}=-3.04+2.48 \operatorname{lnLPL}$ & $0.85^{*}$ \\
\hline & LPL $x$ SIV & 30 & $\mathrm{SIV}=0.03 \mathrm{LPL}^{2.35}$ & $\operatorname{lnSIV}=-3.63+2.35 \operatorname{lnLPL}$ & $0.85^{*}$ \\
\hline & WW x SAL & 31 & $\mathrm{SAL}=16.65 \mathrm{WW}^{0.27}$ & $\operatorname{lnSAL}=2.81+0.27 \ln W W$ & $0.90 *$ \\
\hline & WW x SAW & 31 & $\mathrm{SAW}=8.76 \mathrm{WW}^{0.30}$ & $\operatorname{lnSAW}=2.17+0.30 \ln W W$ & $0.88^{*}$ \\
\hline & WW x SDW & 31 & $\mathrm{SDW}=3.61 \mathrm{WW}^{0.96}$ & $\operatorname{lnSDW}=1.28+0.96 \ln W W$ & $0.92 *$ \\
\hline & WW $x$ SIV & 30 & $\mathrm{SIV}=1.60 \mathrm{WW}^{0.92}$ & $\operatorname{lnSIV}=0.47+0.92 \ln \mathrm{WW}$ & $0.93 *$ \\
\hline
\end{tabular}


Table 2. Continued...

\begin{tabular}{|c|c|c|c|c|c|}
\hline Shell species & Relations & $\mathbf{n}$ & $\begin{array}{c}\text { Linear equation } \\
\mathbf{Y}=\mathbf{a X b}\end{array}$ & $\begin{array}{c}\text { Transformed } \\
\operatorname{lny}=\text { lna }+ \text { blnx }\end{array}$ & $\mathbf{r}$ \\
\hline \multirow[t]{12}{*}{ C. parthenopeum } & SL $\times$ SAL & 26 & $\mathrm{SAL}=3.73 \mathrm{SL}^{1.09}$ & $\operatorname{lnSAL}=1.32+1.09 \operatorname{lnSL}$ & $0.82 *$ \\
\hline & SL $x$ SAW & 26 & $\mathrm{SAW}=1.32 \mathrm{SL}^{1.10}$ & $\operatorname{lnSAW}=0.28+1.10 \operatorname{lnSL}$ & $0.85^{*}$ \\
\hline & SL $x$ SDW & 26 & $\mathrm{SDW}=0.01 \mathrm{SL}^{3.30}$ & $\operatorname{lnSDW}=-4.31+3.30 \operatorname{lnSL}$ & $0.84 *$ \\
\hline & SL $\times$ SIV & 15 & $\mathrm{SIV}=0.01 \mathrm{SL}^{3.03}$ & $\operatorname{lnSIV}=-4.55+3.04 \operatorname{lnSL}$ & $0.95 *$ \\
\hline & LPL x SAL & 26 & $\mathrm{SAL}=3.55 \mathrm{LPL}^{1.00}$ & $\operatorname{lnSAL}=1.27+1.00 \operatorname{lnLPL}$ & $0.81 *$ \\
\hline & LPL $x$ SAW & 26 & $\mathrm{SAW}=1.38 \mathrm{LPL}^{0.97}$ & $\operatorname{lnSAW}=0.32+0.97 \operatorname{lnLPL}$ & $0.80^{*}$ \\
\hline & LPL $x$ SDW & 26 & $\mathrm{SDW}=0.01 \mathrm{LPL}^{2.95}$ & $\operatorname{lnSDW}=-4.25+2.95 \operatorname{lnLPL}$ & $0.80^{*}$ \\
\hline & LPL x SIV & 15 & $\mathrm{SIV}=0.002 \mathrm{LPL}^{3.39}$ & $\operatorname{lnSIV}=-6.04+3.39 \operatorname{lnLPL}$ & $0.95^{*}$ \\
\hline & WW x SAL & 26 & $\mathrm{SAL}=20.69 \mathrm{WW}^{0.34}$ & $\operatorname{lnSAL}=3.03+0.34 \ln W W$ & $0.87 *$ \\
\hline & WW x SAW & 26 & SAW $=7.65 \mathrm{WW}^{0.33}$ & $\operatorname{lnSAW}=2.03+0.33 \ln W W$ & $0.85^{*}$ \\
\hline & WW $x$ SDW & 26 & $\mathrm{SDW}=2.59 \mathrm{WW}^{0.99}$ & $\operatorname{lnSDW}=0.95+1.00 \ln \mathrm{WW}$ & $0.86^{*}$ \\
\hline & WW $x$ SIV & 15 & $\mathrm{SIV}=1.17 \mathrm{WW}^{0.98}$ & $\operatorname{lnSIV}=0.15+0.98 \ln \mathrm{WW}$ & $0.87 *$ \\
\hline
\end{tabular}

n: number of individuals; SL: shield length; LPL: left propodus length; WW: wet weight of hermit crabs; SAL: shell aperture length; SAW: shell aperture width; SDW: shell dry weight; SIV: shell internal volume; and*significant correlation, $\mathrm{P}<0.05)$.

Although the occurrence of another seven hermit crab species in the studied non-consolidated infrallitoral region was registered (Meireles et al., in press), interspecific competition should be a factor with little or no influence in the pattern of shell occupation of the studied population. Such inference is based on the differential spatial distribution, where the specimens of I. sawayai occurred more frequently at a lower depth $(5 \mathrm{~m})$ than the coexistent hermit crab species in the Caraguatatuba region, such as Dardanus insignis (Saussure, 1858), Pagurus exilis (Benedict, 1892) and Loxopagurus loxochelis (Moreira, 1901), and that were registered frequently at 15-20 m of depth (Meireles, 2006; Meireles et al., 2006; Ayres-Peres and Mantelatto, 2008, respectively).

The high number of occupied shell species and relative plasticity indicated that, for the studied population, occupation is influenced by the shell availability. However, considering that almost half of the population occupied S. haemastoma shells, we can infer that there is preference and adaptation of I. sawayai to this shell species. Furthermore, the studies of Hebling and Wernick (1974) and Pinheiro et al. (1993) showed that 67.5 and $80.27 \%$ of $I$. sawayai individuals occupied $S$. haemastoma shells in Peruíbe and Ubatuba, respectively, and this shell species was also occupied by I. sawayai population from Margarita Island, Venezuela (Galindo et al., 2008), observations that corroborated the preference and adaptation to this shell species.

Stramonita haemastoma was significantly the most occupied shell species by all groups of interest, but the patterns of shell occupation that they have exhibited were different. Ovigerous females inhabited lower shell species diversity than males and non ovigerous females, occupying only five of the 17 species occupied by this population. This lower diversity of shell occupation by ovigerous females was similar to that related for Calcinus tibicen (Herbst, 1791) (Garcia and Mantelatto, 2000) and P. exilis (Terossi et al., 2006). This fact consti- tutes a strong indication of shell selection restriction by ovigerous females (Mantelatto and Garcia, 1999).

Furthermore ovigerous females occupied shells with aperture length and dry weight significantly higher than non-ovigerous females. Ovigerous females occupying shells larger than the adequate ones may represent high energetic costs for carrying the shell, to keep it clean of sediment, to defend it during a competition, and to look for food, which may reduce the reproductive output (Fotheringham, 1976a). On the other hand, occupying larger shells may allow the animal to reach its potential growth (Markham, 1968), offer greater protection against predators (Reese, 1969; Vance, 1972b; Siu and Lee, 1992), and specially for the ovigerous females the occupancy of larger shells can result in a fecundity increase (Mantelatto et al., 2002), probably due to greater available space and egg protection (Mantelatto and Garcia, 1999; Mantelatto and Dominciano, 2002). Furthermore, according to Hahn (1998), hermit crabs that occupy heavier shells do not have high energetic costs to carry this shell if the food is transported by water flows, allowing reduced movement, which may probably occur with I. sawayai, a hermit crab species that lives partially buried with its filtering antennas vertically positioned to the water current (Melo, 1999).

A differential pattern of shell occupation among the sexes should be related to male and female different preferences, to a competitive dominance of a sex, to both factors (Yoshino et al., 2001), or to different size rates among sexual groups (Abrams, 1988). Males hermit crabs are usually larger than females (Fransozo and Mantelatto, 1998; Manjón-Cabeza and GarcíaRaso, 1998; Mantelatto and Sousa, 2000; Garcia and Mantelatto, 2001; Branco et al., 2002; Martinelli et al., 2002; Litulo, 2005a; 2005b; Mantelatto et al., 2005; Biagi et al., 2006) mainly because of the differential energy investment they present, females must divert part of this energy to the reproductive process while males invest in 
growth (Abrams, 1988; Mantelatto and Martinelli, 2001; Fransozo et al., 2003). Furthermore, the larger sized males have a greater probability of success in copulating because they can fertilize females of different sizes as well as having the advantage in fighting for acquiring females (Hazlett and Baron, 1989). Differential growth patterns between the sexes may influence shell species occupation (Abrams, 1988) and this may be the most probable cause of the different pattern of shell occupation exhibited by the studied population associated to the possible competitive dominance of males over females in the shell fighting process.

In the present study, the same shell species was the most occupied by all groups of interest, which is an indication that there are no differential preferences among the sexes determining different patterns of occupation. In this way, the most probable reason for the occupation difference was the differential growth among the sexes and the competitive dominance of larger males, factors that could be related to the occupation of different shell species and sizes between sexes.

In relation to the shell occupation by individuals of different size classes it was verified that intermediate sized individuals of this population occupied a greater diversity of shell species, a fact that was also observed in the studies realized with Petrochirus diogenes (Linnaeus, 1758), C. tibicen, Paguristes tortugae Schmitt, 1933, Pagurus brevidactylus (Stimpson, 1859) and Paguristes calliopsis Forest and Saint Laurent (1968) (Bertini and Fransozo, 2000; Mantelatto and Garcia, 2000; Mantelatto and Dominciano, 2002; Mantelatto and Meireles, 2004; Biagi et al., 2006, respectively). This can be related to the reduced intraspecific shell competition capacity against the largest individuals for the most adequate shells (Dowds and Elwood, 1983), or to the presence of a greater number of intermediate sized shell species available in the environment (Mantelatto and Garcia, 2000), since the smaller the hermit crabs is, the greater is the shell diversity it can find (Reese, 1969). Thus, small hermit crabs may not be considered so dependent on a determinate gastropod shell species as the big ones are (Bollay, 1964), and are frequently encountered inhabiting adequate shells when compared to the larger individuals, mainly because of the greater shell availability to the small and intermediate individuals (Vance, 1972a; Bertness, 1980).

According to Conover (1979), the epibionts that inhabit a gastropod shell are influenced by the shell size and by the presence or absence of a hermit crab, and also some symbionts have a greater survival probability when associated to a hermit crab. Little is known about the costs and benefits of the association between hermit crabs and other invertebrates, but their presence can affect shell selection and occupation by hermit crabs (Martinelli and Mantelatto, 1998). More than half $(57.37 \%)$ of the I. sawayai studied population occupied infested shells. Bryozoans were the epibiont group with greatest occurrence being present in $42.36 \%$ of the occupied shells, which was similar to that observed for L. loxochelis (Martinelli and Mantelatto, 1998). According to these authors, the occupation of shells covered by bryozoans can be due to the great abundance of these epibionts in the environment, and is related to the burying behavior of some hermit crab species, such as I. sawayai, conferring camouflage on sand.

Regression analysis between all hermit crabs and shell dimensions showed significant and high correlation coefficient values. This fact is an important indication that, although there is a reduced number of resources available in the environment (Meireles, 2006), the hermit crabs were occupying adequate shells.

Therefore, we can infer that I. sawayai shows a high plasticity in the pattern of shell occupation that is related to the resource availability in the environment and to a possible preference for S. haemastoma. Furthermore, the fact of occupying adequate shells may represent that, for this population, the shells may not be considered a limiting resource, but laboratory experiments are needed for a better understanding of the shell preference and adequacy for the I. sawayai population studied.

Acknowledgements - This work was part of a B.Sc. thesis of MZF and was supported by Scientific Initiation Fellowships from PIBIC/CNPq. RB and FLM are grateful to CNPq for Post Doctoral and Research fellowships. Special thanks are due to Dr Adilson Fransozo for support and facilities during sampling collections provided by the FAPESP-Biota Program (Proc. 98/070900-3), and to all NEBECC colleagues and to members of the Laboratory of Bioecology and Crustacean Systematics of FFCLRP/USP for their help during field and laboratory work. The support of the Postgraduate Program in Comparative Biology of FFCLRP/USP and the Centro de Biologia Marinha (CEBIMar/USP) during field work is gratefully acknowledged. All experiments conducted in this study comply with current applicable state and federal laws.

\section{References}

ABRAMS, PA., 1980. Resource partitioning and interspecific competition in a tropical hermit crab community. Oecologia, vol. 46 , no. 3 , p. 365-379.

-, 1988. Sexual difference in resource use in hermit crabs: consequences and causes. In: Chelazzi, G. and Vannini, M. (Eds.). Behavioral adaptations to intertidal life. New York: Plenum.

AYRES-PERES, L. and MANTELATTO, FL., 2008. Análise comparativa da estrutura populacional do ermitão endêmico do Atlântico Ocidental Loxopagurus loxochelis (Decapoda, Anomura) em duas regiões do estado de São Paulo, Brasil. Iheringia, Sér. Zool., vol. 98, no. 1, p. 28-35.

BACH, C., HAZLETT, B. and RITTSCHOF, D., 1976. Effects of interspecific competition on fitness of the hermit crab Clibanarius tricolor. Ecology, vol. 57, no. 3, p. 579-586.

BERTNESS, MD., 1980. Shell preference and utilization patterns in littoral hermit crabs of the Bay of Panama. J. Exp. Mar. Biol. Ecol., vol. 48, no. 1, p. 1-16. 
-, 1981a. Conflicting advantages in resource utilization: the hermit crab housing dilemma. Am. Nat., vol. 118, no. 3, p. $432-437$.

-, 1981b. The influence of shell-type on hermit crab growth, rate and clutch size (Decapoda, Anomura). Crustaceana, vol. 40, no. 2, p. 197-205.

-, 1982. Shell utilization, predation pressure, and thermal stress in panamanian hermit crabs: an interoceanic comparison. $J$. Exp. Mar. Biol. Ecol., vol. 64, no. 2, p. 159-197.

BERTINI, G. and FRANSOZO, A., 2000. Patterns of shell utilization in Petrochirus diogenes (Decapoda, Anomura, Diogenidae) in the Ubatuba region, São Paulo, Brazil. J. Crust Biol., vol. 20, no. 3, p. 468-473.

BIAGI, R., MEIRELES, AL. and MANTELATTO, FL., 2006. Bio-ecological aspects of the hermit crab Paguristes calliopsis (Crustacea, Diogenidae) from Anchieta Island, Brazil. An. Acad. Bras. Cienc., vol. 78, no. 3, p. 451-462.

BOLLAY, M., 1964. Distribution and utilization of gastropod shells by the hermit crabs Pagurus samuelis, Pagurus granosimanus, and Pagurus hirsutiusculus at Pacific Grove, California. Veliger, vol. 6, no. suppl., p. 71-76.

BRANCO, JO., TURRA, A. and SOUTO, FX., 2002. Population biology and growth of the hermit crab Dardanus insignis at Armação do Itapocoroy, southern Brazil. J. Mar. Biol. Ass. U. K., vol. 82, no. 4, p. 597-603.

CHILDRESS, JR., 1972. Behavioral ecology and fitness theory in a tropical hermit crab. Ecology, vol. 53, no. 5, p. 960-964.

COELHO, PA. and RAMOS, MA., 1972. A constituição e a distribuição da fauna de decápodos do litoral leste da América do Sul, entre as latitudes de $5^{\circ} \mathrm{N}$ e $39^{\circ} \mathrm{S}$. Trabls. Oceanogr. Univ. Fed. Pe., vol. 13, p. 133-236.

CONOVER, MR., 1978. The importance of various shell characteristics to the shell-selection behavior of hermit crabs. $J$. Exp. Mar. Biol. Ecol., vol. 32, no. 2, p. 131-142.

-, 1979. Effect of gastropod shell characteristics and hermit crabs on shell epifauna. J. Exp. Mar. Biol. Ecol., vol. 40, no. 1, p. 81-94.

DOMINCIANO, LCC. and MANTELATTO, FL., 2004. The influence of shell species and size on the shell selection pattern of Paguristes tortugae (Decapoda, Diogenidae) from Anchieta Island (Ubatuba, Brazil). Iheringia, Sér. Zool., vol. 94, no. 4, p. $425-428$.

DOWDS, BM. and ELWOOD, RW., 1983. Shell wars: assessment strategies and the timing of decisions in hermit crab shell fights. Behaviour, vol. 85, no. 1-2, p. 1-24.

FLOETER, SR., NALESSO, RC., RODRIGUES, MMR. and TURRA, A., 2000. Patterns of shell utilization and selection in two sympatric hermit crabs (Anomura, Diogenidae) in south-eastern Brazil. J. Mar. Biol. Ass. U. K., vol. 80, no. 6, p. 1053-1059.

FOTHERINGHAM, N., 1976a. Hermit crab shells as a limiting resource (Decapoda, Paguridea). Crustaceana, vol. 31, no. 2, p. 193-199.

-, 1976b. Population consequences of shell utilization by hermit crabs. Ecology, vol. 57, no. 3, p. 570-578.

FRANSOZO, A. and MANTELATTO, FL., 1998. Population structure and reproductive period of the tropical hermit crab Calcinus tibicen (Decapoda: Diogenidae) in the region of Ubatuba, São Paulo, Brazil. J. Crust Biol., vol. 18, no. 4, p. $738-745$

FRANSOZO, A., GARCIA, RB. and MANTELATTO, FL., 2003. Morphometry and sexual maturity of the tropical hermit crab Calcinus tibicen (Crustacea, Anomura) from Brazil. J. Nat. Hist., vol. 37, no. 3, p. 297-304.

GALINDO, LA., BOLAÑOS, JA. and MANTELATTO, FL., 2008. Shell utilization pattern by the hermit crab Isocheles sawayai Forest and Saint Laurent, 1968 (Anomura, Diogenidae) from Margarita Island, Caribbean Sea, Venezuela. Carib. J. Sci., vol. 20 , no. 1 , p. $49-57$.

GARCIA, RB. and MANTELATTO, FL., 2000. Variability of shell occupation by intertidal and infralittoral Calcinus tibicen (Anomura: Diogenidae) populations. Nauplius, vol. 8, no. 1, p. 99-105.

-, 2001. Population dynamics of the hermit crab Paguristes erythrops (Diogenidae) from Anchieta Island, southern Brazil. J. Mar. Biol. Ass. U. K., vol. 81, no. 6, p. 955-960.

GARCIA, RB., MEIRELES, AL. and MANTELATTO, FL., 2003. Unusual shelters occupied by Brazilian hermit crabs (Crustacea: Decapoda: Diogenidae). Braz. J. Biol. $=$ Rev. Bras. Biol., vol. 63, no. 4, p. 721-722.

HAHN, DR., 1998. Hermit crab shell use patterns: response to previous shell experience and to water flow. J. Exp. Mar. Biol. Ecol., vol. 228, no. 1, p. 35-51.

HAZLETT, BA., 1981. The behavioral ecology of hermit crabs. Annu. Rev. Ecol. Syst., vol. 12, no. 1, p. 1-22.

HAZLETT, BA. and BARON, LC., 1989. Influence of shells on mating behavior in the hermit crab Calcinus tibicen. Behav. Ecol. Sociobiol., vol. 24, no. 6, p. 369-376.

HEBLING, NJ. and WERNICK, AM., 1974. Notas sobre Isocheles sawayai (Forest, 1967) (Decapoda, Paguridea). Cienc. Cult. (Supl.), vol. 26, no. 7, p. 335.

KELLOG, CW., 1976. Gastropod shells: a potentially limiting resource for hermit crabs. J. Exp. Mar. Biol. Ecol., vol. 22, no. 1, p. 101-111.

LANCASTER, I., 1988. Pagurus bernhardus (L.) - An introduction to the natural history of hermit crabs. Field Stud., vol. 7, p. 189-238.

LITULO, C., 2005a. Population structure and reproduction of the hermit crab Dardanus deformis (Anomura: Diogenidae) in the Indian Ocean. J. Mar. Biol. Ass. U. K., vol. 85, no. 4, p. $883-887$.

-, 2005b. Population biology and fecundity of the Indo-Pacific hermit crab Clibanarius longitarsus (Anomura: Diogenidae). J. Mar. Biol. Ass. U. K., vol. 85, no. 1, p. 121-125.

MANJÓN-CABEZA, ME. and GARCÍA-RASO, JE., 1998. Population structure and growth of the hermit crab Diogenes pugilator (Decapoda: Anomura: Diogenidae) from the northeastern Atlantic. J. Crust Biol., vol. 18, no. 4, p. 753-762.

MANTELATTO, FL. and GARCIA, RB., 1999. Reproductive potential of the hermit crab Calcinus tibicen (Anomura) from Ubatuba, São Paulo, Brazil. J. Crust. Biol., vol. 19, no. 2, p. 268-275. 
MANTELATTO, FL. and GARCIA, RB., 2000. Shell utilization pattern of the hermit crab Calcinus tibicen (Diogenidae) from southern Brazil. J. Crust Biol., vol. 20, no. 3, p. 460-467.

MANTELATTO, FL. and SOUSA, LM., 2000. Population biology of the hermit crab Paguristes tortugae Schimitt, 1933 (Anomura, Diogenidae) from Anchieta Island, Ubatuba, Brazil. Nauplius, vol. 8, no. 2, p. 185-193.

MANTELATTO, FL. and MARTINELLI, JM., 2001. Relative growth and sexual dimorphism of the South Atlantic hermit crab Loxopagurus loxochelis (Anomura, Diogenidae) from Ubatuba, Brazil. J. Nat. Hist., vol. 35, no. 3, p. 429-437.

MANTELATTO, FL. and DOMINCIANO, LCC., 2002. Pattern of shell utilization by the hermit crab Paguristes tortugae (Diogenidae) from Anchieta Island, southern Brazil. Sci. Mar., vol. 66, no. 3, p. 265-272.

MANTELATTO, FL. and MEIRELES, AL., 2004. The importance of shell occupation and shell availability in the hermit crab Pagurus brevidactylus (Stimpson, 1859) (Paguridae) population from the southern Atlantic. Bull. Mar. Sci., vol. 75, no. 1, p. 27-35.

MANTELATTO, FL., ALARCON, VF. and GARCIA, RB., 2002. Egg production strategies of the tropical hermit crab Paguristes tortugae from Brazil. J. Crust. Biol., vol. 22, no. 2, p. 390-397.

MANTELATTO, FL., CHRISTOFOLETTI, RA. and VALENTI, WC., 2005. Population structure and growth of the hermit crab Pagurus brevidactylus (Anomura: Paguridae) from the northern coast of São Paulo, Brazil. J. Mar. Biol. Ass. U. K., vol. 85, no. 1, p. 127-128.

MARKHAM, JC., 1968. Notes on the growth-patterns and shell-utilization of the hermit crab Pagurus bernhardus (L.). Ophelia, vol. 5, p. 189-205.

MARTINELLI, JM. and MANTELATTO, FL., 1998. Occurrence of exobionts in gastropod shells occupied by the hermit crab Loxopagurus loxochelis (Anomura: Diogenidae) in Ubatuba bay (SP), Brazil. In: Anais do IV Simpósio de Ecossistemas Brasileiros. São Paulo: Publ. ACIESP, 1998, vol. 2, no. 104, p. 221-226.

MARTINELLI, JM., MANTELATTO, FL. and FRANSOZO A., 2002. Population structure and breeding season of the south Atlantic hermit crab, Loxopagurus loxochelis (Anomura, Diogenidae) from the Ubatuba region, Brazil. Crustaceana, vol. 75 , no. 6, p. 791-802.

MEIRELES, AL., 2006. Estudo comparativo da distribuição espaço-temporal, da estrutura populacional e da relação de simbiose entre o ermitão Dardanus insignis (de Saussure, 1858) (Anomura, Diogenidae) e o porcelanídeo Porcellana sayana (Leach, 1820) (Anomura, Porcellanidae) no litoral norte paulista. Ribeirão Preto: FFCLRP-USP. 313 p. [Doctoral thesis].

MEIRELES, AL. and MANTELATTO, FL., 2005. Shell use by the Pagurus brevidactylus (Anomura, Paguridae): a comparison between laboratory and field conditions. Acta Zool. Sinica, vol. 51 , no. 5 , p. $813-820$

MEIRELES, AL., BIAGI, R. and MANTELATTO, FL., 2003. Gastropod shell availability as a potential resource for the hermit crab infralittoral fauna of Anchieta Island (SP), Brazil. Nauplius, vol. 11, no. 2, p. 99-105.

MEIRELES, AL., TEROSSI, M., BIAGI, R. and MANTELATTO FL., 2006. Spatial and seasonal distribution of the hermit crab Pagurus exilis (Benedict, 1892) (Decapoda: Paguridae) in the southwestern coast of Brazil. Rev. Biol. Mar. Ocean., vol. 41, no. 1, p. $87-95$.

MEIRELES, AL., BIAGI, R., FRANSOZO, A. and MANTELATTO, FL. Os Ermitões (Crustacea, Anomura). In: Amaral, ACZ. and Nallin, SAH. (Eds.). Biodiversidade e ecossistemas bentônicos marinhos do litoral norte de São Paulo - sudeste do Brasil. In press.

MELO, GAS., 1999. Manual de identificação dos Crustacea Decapoda do litoral brasileiro: Anomura, Thalassinidea, Palinuridea e Astacidea. São Paulo: Plêiade Editora. 551 p.

NUCCI, PR. and MELO, GAS., 2000. Range extensions for eight species of western Atlantic hermit crabs (Crustacea, Paguroidea). Nauplius, vol. 8, no. 1, p. 141-147.

PINHEIRO, MAA., FRANSOZO, A. and NEGREIROSFRANSOZO, ML., 1993. Seleção e relação com a concha em Isocheles sawayai Forest \& Saint-Laurent, 1967 (Crustacea, Anomura, Diogenidae). Arq. Biol. Tecnol., vol. 36, no. 4, p. $745-752$

PROVENZANO Jr., AJ., 1960. Notes on Bermuda hermit crabs (Crustacea, Anomura). Bull. Mar. Sci. Gulf Carib., vol. 10, no. 1 , p. 117-124.

REESE, ES., 1969. Behavioral adaptations of intertidal hermit crabs. Amer. Zool., vol. 9, no. 2, p. 343-355.

RIOS, EC., 1994. Seashells of Brazil. 2 ed. Rio Grande: Editora FURG. 492 p.

SCULLY, EP., 1983. The effects of shell availability on intraspecific competition in experimental populations of the hermit crab, Pagurus longicapus Say. J. Exp. Mar. Biol. Ecol., vol. 71 , no. 3, p. 221-236.

SIU, BFC. and LEE, SY., 1992. Shell preference and utilization pattern in two hermit crabs, Pagurus trigonocheirus (Stimpson) and Clibanarius bimaculatus (de Haan), on a sheltered rocky shore in Hong Kong. Asian Mar. Biol., vol. 9, p. 205-216.

TEROSSI, M., ESPÓSITO, DLA., MEIRELES, AL., BIAGI, R. and MANTELATTO, FL., 2006, Pattern of shell occupation by the hermit crab Pagurus exilis (Anomura, Paguridae) on the northern coast of São Paulo state, Brazil. J. Nat. Hist., vol. 40, no. 1-2, p. 77-87.

VANCE, RR., 1972a. Competition and mechanism of coexistence in three sympatric species of intertidal hermit crabs. Ecology, vol. 53, no. 6, p. 1062-1074.

-, 1972b. The role of shell adequacy in behavioral interactions involving hermit crabs. Ecology, vol. 53, no. 6, p. 1075-1083.

YOSHINO, K., GOSHIMA, S. and NAKAO, S., 2001. Sexual difference in shell use in the hermit crab Pagurus filholi (de Man) from northern Japan. Crust. Res., vol. 30, p. 55-64.

ZAR, JH., 1996. Biostatistical analysis. New Jersey: PrenticeHall. 907 p. 